\title{
Fuzzy logic modelling to predict the level of geotechnical risks in rock Tunnel Boring Machine (TBM) tunnelling
}

The Mining-Geology-Petroleum Engineering Bulletin UDC: $624.1 ; 622.8$

DOI: $10.17794 / \operatorname{rgn} .2020 .2 .1$

Original scientific paper

\author{
Mohammad Hossein Arbabsiar'; Mohammad Ali Ebrahimi Farsangi ${ }^{1}$; Hamid Mansouri ${ }^{1}$ \\ ${ }^{1}$ Mining Engineering Department, Shahid Bahonar University of Kerman, Kerman, Iran
}

\begin{abstract}
This study aims to analyze the level of geotechnical risks and predict the advance rate in rock Tunnel Boring Machine (TBM) tunnelling, using a multi-stage fuzzy logic modelling. Twelve parameters, affecting the geotechnical hazard scenario occurrence, which were clustered into five groups, were used as input parameters and the risk level was used as an output parameter. Also, based on the relation between the risk levels and advance rates, a predictive model for advance rate prediction was proposed. To validate the performance of modelling carried out, data from 58 geological zones in section two of the Zagros tunnel, Iran were used. The obtained results showed that by using the fuzzy logicbased model, in most zones, the risk levels estimated are in good agreement with field observations. Moreover, as expected, the high coefficient of determination $\left(\mathrm{R}^{2}\right)$ of 0.91 between the risk level estimated and the average advance rate achieved in 58 analyzed zones, confirms the ability of the model proposed to predict the level of geotechnical risks. Furthermore, $\mathrm{R}^{2}=0.93$, Root Mean Square Error (RMSE) of 0.62 and Variance Accounted For (VAF) of 97.51 between the measured and predicted advance rates show the good performance of the new predictive model developed for the advance rate estimation.
\end{abstract}

Keywords:

Geotechnical risk, TBM tunnelling, Fuzzy logic, Zagros tunnel

\section{Introduction}

While tunnel driving, there might be a considerable potential of geotechnical risks due to facing different hazard scenarios such as muddy conditions, fault zones, squeezing, instability, water inflow, mixed ground, gas inflow, which threaten the achievement of the advance rates, costs, and the planned schedule. Also, for tunnels in urban areas, a range of properties and third-party persons are under the risk of damage. To reduce the risk of facing such hazard scenarios in TBM tunnelling, it is required to evaluate areas which may endanger the operation of tunnelling and to identify the risk level associated with such hazard scenarios. Risk assessment has been one of the key issues in the field of geotechnical engineering. In 1993, risk assessment of rockfall prone areas was carried out by Cancelli and Crosta. In 1996, Sturk et al. used risk and decision analysis for large underground projects. The concept of risk and risk analysis in rock engineering was introduced by Einstein in 1996. A methodology based on the Rock Engineering Systems (RES) concept; first introduced by Hudson in 1992, for assessing geotechnical hazards for TBM tunnelling was proposed by Benardos and Kaliampakos in 2004. Risk

Corresponding author: Mohammad Ali Ebrahimi Farsangi maebrahimi@uk.ac.ir analysis was used by You et al. (2005) to obtain a tunnel support pattern. In 2007, a landslide risk rating system for Baguio, Philippines was introduced by SaldivarSali and Einstein. A geotechnical risk assessment-based approach for rock TBM selection in difficult ground conditions was applied by Shahriar et al. in 2008. Jian et al. (2009) applied a fuzzy neural network approach to predict the risk of rockburst. A methodology for quantitative hazard assessment for tunnel collapses was proposed by Shin et al. in 2009. Hong et al. (2009) utilized a quantitative risk evaluation based on the event tree analysis technique to design a shield TBM. Khademi Hamidi et al. (2010a) used fuzzy-AHP for a risk assessment-based selection of rock TBM in adverse geological conditions. Sousa and Einstein (2012) applied Bayesian Networks (BN) for risk analysis during tunnel construction. Moradi and Ebrahimi (2014) Farsangi used the risk matrix method to estimate the level of geotechnical risks in the Zagros tunnel, Iran. Hyun et al (2015) used Fault Tree Analysis (FTA) and Analytic Hierarchy Process (AHP) to perform risk analysis in shield TBM tunnels. Fattahi and Moradi (2017) applied a RESbased model for risk assessment and an estimation of TBM penetration.

In this paper, the main objective is to propose a fuzzy logic model for the prediction of the level of geotechnical risks in rock TBM tunnelling. The novelty of this 
Table 1: Sample of the datasets used in the modelling

\begin{tabular}{|l|c|c|c|c|c|c|c|c|c|c|c|c|c|c|}
\hline Zone & $\begin{array}{c}\mathbf{R Q D} \\
\mathbf{( \% )}\end{array}$ & $\mathbf{J C}$ & $\begin{array}{c}\boldsymbol{\alpha} \\
\left({ }^{\circ}\right)\end{array}$ & $\begin{array}{c}\gamma \\
\left({ }^{\circ}\right)\end{array}$ & $\mathbf{K I}$ & $\begin{array}{c}\text { QC } \\
\mathbf{( \% )}\end{array}$ & $\begin{array}{c}\mathbf{C M} \\
\mathbf{( \% )}\end{array}$ & $\begin{array}{c}\mathbf{U C S} \\
(\mathbf{M P a})\end{array}$ & $\begin{array}{c}\mathbf{G W} \\
(\mathbf{l i t / 5 / 1 0} \mathbf{m})\end{array}$ & $\mathbf{S Q}$ & $\begin{array}{c}\mathbf{C H}_{4} \\
\mathbf{( \% )}\end{array}$ & $\begin{array}{c}\mathbf{H}_{\mathbf{2}} \mathbf{S} \\
(\mathbf{p p m})\end{array}$ & $\begin{array}{c}\mathbf{C Z} \\
(\mathbf{m})\end{array}$ & $\begin{array}{c}\text { Measured AR } \\
(\mathbf{m} / \mathbf{d a y})\end{array}$ \\
\hline SH-ML1 & 72 & 0.7 & 90 & 25 & 0.15 & 2.5 & 55 & 20 & 130 & 2.3 & 2 & 10 & - & 20 \\
\hline SH-ML2 & 56 & 0.5 & 80 & 50 & 0.15 & 2.5 & 55 & 23 & 140 & 1.5 & 3 & 10 & - & 14 \\
\hline SH-ML1 & 72 & 0.7 & 90 & 25 & 0.15 & 2.5 & 55 & 23 & 155 & 1.2 & 3 & 11 & - & 18 \\
\hline CZ1 & 23 & 0.25 & - & - & 0.15 & 2.5 & 10 & 5 & 165 & 1.3 & 2 & 10 & 17 & 12 \\
\hline ML-SH1 & 79 & 0.8 & 70 & 50 & 0.25 & 2.5 & 40 & 75 & 158 & 8.5 & 2 & 10 & - & 20 \\
\hline SH-ML3 & 58 & 0.7 & 110 & 85 & 0.15 & 2.5 & 40 & 15 & 160 & 1 & 3 & 11 & - & 16 \\
\hline ML-SH2 & 65 & 0.7 & 90 & 25 & 0.25 & 2.5 & 40 & 23 & 180 & 1.6 & 2 & 12 & - & 16 \\
\hline ML-SH3 & 58 & 0.7 & 85 & 25 & 0.25 & 2.5 & 40 & 38 & 170 & 1.8 & 3 & 12 & - & 20 \\
\hline ML-SH2 & 65 & 0.7 & 50 & 65 & 0.25 & 2.5 & 40 & 23 & 175 & 1.6 & 2.5 & 12 & - & 18 \\
\hline SH-ML3 & 58 & 0.6 & 135 & 30 & 0.15 & 2.5 & 55 & 15 & 168 & 0.8 & 3.5 & 11 & - & 16 \\
\hline
\end{tabular}

Table 2: Descriptive statistics of the obtained data from section two of the Zagros tunnel

\begin{tabular}{|c|c|c|c|c|c|}
\hline NO. & Parameter & Min. & Max. & Mean & St. Dev. \\
\hline 1 & RQD (\%) & 22 & 85 & 61 & 17 \\
\hline 2 & Joint condition $\left(\mathrm{J}_{\mathrm{c}}\right)$ & 0.25 & 0.80 & 0.62 & 0.18 \\
\hline 3 & Joint dip $(\gamma)\left(^{\circ}\right)$ & 20 & 85 & 43.20 & 20.70 \\
\hline 4 & $\begin{array}{l}\text { Joint dip direction } \\
(\boldsymbol{\alpha})\left(^{\circ}\right)\end{array}$ & 10 & 144 & 86.50 & 21.71 \\
\hline 5 & Karstic index (KI) & 0.10 & 0.40 & 0.20 & 0.07 \\
\hline 6 & $\begin{array}{l}\text { Quartz contents }(\mathrm{QC}) \\
(\%)\end{array}$ & 0.5 & 4 & 1.9 & 0.9 \\
\hline 7 & $\begin{array}{l}\text { Clay minerals }(\mathrm{CM}) \\
(\%)\end{array}$ & 5 & 70 & 22.5 & 20 \\
\hline 8 & UCS (MPa) & 4 & 125 & 31 & 26 \\
\hline 9 & $\begin{array}{l}\text { Groundwater }(\mathrm{GW}) \\
(\mathrm{lit} / \mathrm{s} / 10 \mathrm{~m})\end{array}$ & 6 & 300 & 59 & 92 \\
\hline 10 & Squeezing (SQ) & 0.2 & 2.3 & 0.9 & 0.5 \\
\hline 11 & $\mathrm{CH}_{4}(\%)$ & 2 & 30 & 14 & 7.9 \\
\hline 12 & $\mathrm{H}_{2} \mathrm{~S}(\mathrm{ppm})$ & 7 & 80 & 38 & 21 \\
\hline 13 & $\begin{array}{l}\text { Width of crushed } \\
\text { zone }(\mathrm{CZ})(\mathrm{m})\end{array}$ & 20 & 120 & 39 & 34 \\
\hline 14 & $\begin{array}{l}\text { Advance rate (AR) } \\
(\mathrm{m})\end{array}$ & 8 & 20 & 16 & 3 \\
\hline
\end{tabular}

Min: Minimum; Max: Maximum; St. Dev.;

Standard deviation

research is using the benefits of fuzzy logic modelling. Fuzzy logic modelling is based on expert views, which is a good choice for ground modelling. Also, the model defined is not site dependant and can be applied for the other tunnelling sites if the same parameters are used. In the modelling, 12 parameters are utilized as input parameters and the level of risk as an output parameter. In order to avoid too many input parameters in the fuzzy modelling, they are categorized into five groups and multi-stage fuzzy modelling is applied. Performance evaluation of the new model is carried out using field data collected from the $12 \mathrm{~km}$ tunnel excavated in sec- tion two of the Zagros tunnel, Iran. The results of this research work may be used for the prediction of risk levels before tunnel driving.

\section{Description of site and data collection}

The Zagros tunnel is situated in the west of Iran. It consists of two sections with a total length of $52 \mathrm{~km}$. The study area; section two, with an excavation diameter of $6.73 \mathrm{~m}$, a length of $26 \mathrm{~km}$, and overburden of $20 \mathrm{~m}$ to $1000 \mathrm{~m}$ was excavated by a double-shield TBM. This part of the tunnel passes through several rock formations with a RMR of 17 to 75 . The water table varies between $30 \mathrm{~m}$ to $340 \mathrm{~m}$ above the tunnel profile. Based on geological and geotechnical studies, different zones were recognized in this part of the tunnel, which mostly consists of shale, limestone, and marl layers. The zones through the tunnel alignment were named based on the dominant lithological characteristics such as MA (marl), SH (shale), LI (limestone), CZ (crushed zone), LI-MA (marly-limestone), FZ (fractured zone), and LI-SH (limy shale). Also, the tunnel in section two intersects with 23 different types of faults (Lar consulting engineers, 2004).

Data was collected from a surface field study along the alignment of the tunnel as well as 25 drilled boreholes, which were used to develop a database for section two of the Zagros tunnel. The obtained core samples from boreholes were utilized to determine quartz content, porosity, density, karstic conditions, water absorption, and clay content. Also, the permeability of each zone, using the Lugeon test, was obtained. The uniaxial compressive test was used to measure Uniaxial Compressive Strength (UCS), elastic modulus and the Poisson ratio. Moreover, tensile strength was obtained using the Brazilian test. Finally, friction angle and coefficient of cohesion of joints and rocks were obtained using direct shear and triaxial compressive tests. Also, using the International Society of Rock Mechanics (ISRM) standards, surface joint study programs along the tunnel 


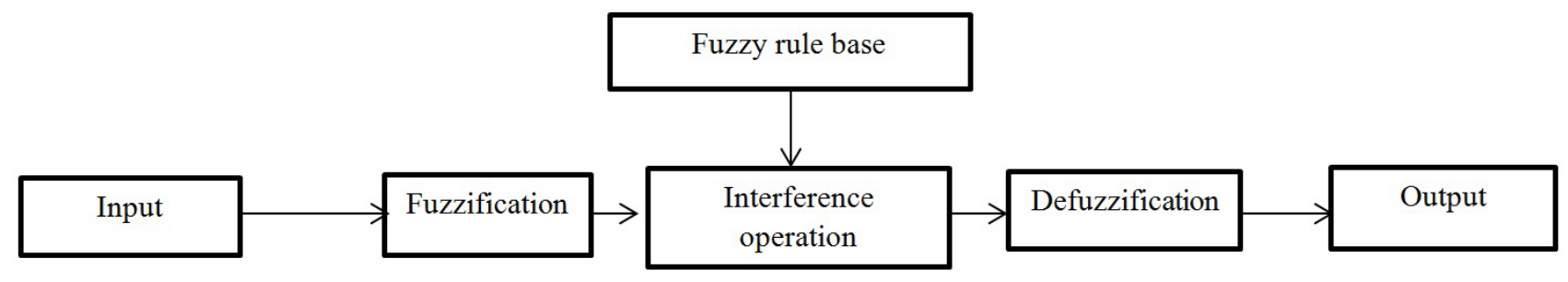

Figure 1: A fuzzy system

alignment were carried out in which, dip direction, dip, aperture, roughness, spacing, persistence, filling, water condition, waviness, and the weathering of joints were determined. Also, boreholes were used to measure gas inflow and water inflow conditions in different zones and data was obtained through a hydrogeological study program. In addition, real measurements during tunnel excavation, such as water inflow and the amount of gas emission were used for validation and adjustment of the database in this research.

The obtained data from section two of the Zagros tunnel was used for developing a geotechnical risk model. This database contains Rock Quality Designation (RQD), joint condition $\left(J_{c}\right)$, joint orientation $(\operatorname{dip}(\gamma)$ and dip direction $(\boldsymbol{\alpha})$ ), Karstic Index $(\mathrm{KI})$, abrasive rock (Quartz Content (QC)), Clay Minerals (CM) in rock mass, gas emission $\left(\mathrm{CH}_{4}\right.$ and $\left.\mathrm{H}_{2} \mathrm{~S}\right)$, UCS, Squeezing (SQ), Ground Water inflow (GW), and width of Crushed Zone (CZ) as input parameters for the model.

Advance Rate (AR) was measured through on-board TBM equipment and was averaged for each zone. The sample of the datasets used in the modelling is listed in Table 1. Also, descriptive statistics for the data collected from 58 zones in the first $12 \mathrm{~km}$ of tunnel excavated in section two of the Zagros tunnel are presented in Table 2.

\section{Fuzzy systems}

Zadeh in 1965 introduced the concept of fuzzy set theory in which linguistical vagueness is represented in a mathematical way. In a classical set, the membership of an element is crisp [0, 1] (Equation 1), but in a fuzzy set, the degree of membership for each element ranges from zero to one (Equation 2).

Where:

$$
\mu_{A}(x)=\left\{\begin{array}{l}
1 \text { if } x \in A \\
0 \text { if } x \notin A
\end{array}\right.
$$

$A$ - Crisp set,

$\mu_{A}-$ An element membership of $\mathrm{x}$ in the crisp set A.

$$
A=\left\{x, \mu_{A}(x) \mid x \in U\right\}
$$

Where:

$U$ - A defined universe of discourse for a particular problem,

$\mu_{A}(x)$ - The degree of membership of the variable $x$ $\left(\mu_{A}(x) \rightarrow[0,1]\right)$.
Fuzzy systems mainly consist of four elements: crisp values fuzzification, fuzzy rule base, fuzzy inference systems, and fuzzy values defuzzification (see Figure 1). The fuzzification process converts crisp input values to fuzzy values by the defined membership functions. It is dependent on the nature of the problem to use either linear (triangular, trapezoidal) or non-linear forms of membership functions (Acaroglu et al., 2008). The fuzzy rule base, if-then rules are carried out to describe the input-output relationships. Mapping of input to output is carried out by the Fuzzy Inference System (FIS), using if-then rules and fuzzy reasoning. Different FISs such as Takagi-Sugeno-Kang (TSK), Mamdani, Singeleton, and Tsukamoto models are used in different fields. However, the Mamdani model is the most commonly used FIS due to its popularity and easy application (Iphar and Goktan, 2006).

Different composition methods, such as min-min, max-min, min-max, and max-max, are used on fuzzy relations. Between these relations, the max-min is the most commonly used (Ross, 1995). Finally, the result of the inference system (fuzzy output value) defuzzifies to a crisp output value by defuzzification methods such as the centre of gravity, Centroid of Area (COA), smallest of the maximums, and the mean of maximums. Between these defuzzification methods, the COA method is the most widely used (Alvarez Grima, 2000).

Different research carried out in the field of geomechanics and mining, using fuzzy logic modelling. Samples of the research are shown below:

A fuzzy model for the prediction of the unconfined compressive strength of rock samples was carried out by Alvarez Grima and Babuska (1999). In 1999, Grima and Verhoef used fuzzy logic modelling to forecast rock trencher performance. A neuro-fuzzy method for modelling TBM performance was employed by Alvarez Grima et al. (2000). An application of fuzzy sets to the diggability index rating method for surface mine equipment selection was introduced by Iphar and Goktan (2006). Fuzzy logic for extending the Q system's prediction of support in tunnels was applied by Tzamos and Sofianos (2006). Further, a fuzzy logic model to predict the specific energy requirements for TBM performance prediction was proposed by Acaroglu et al. (2008). In addition, a fuzzy neural network for predicting the risk of rockburst was applied by Jian et al. in 2009. Also, it was shown by Monjezi et al. (2009) that fuzzy logic model- 
ling can be applied for the prediction of rock fragmentation due to blasting. Furthermore, the application of fuzzy logic to determine coal mine mechanization was addressed by Ataei et al. in 2009.

Khademi Hamidi et al. (2010b) applied a fuzzy set theory to rock engineering classification systems for illustration of the index of rock mass excavability. Fuzzy logic models were applied for the prediction of thrust and torque requirements of TBMs by Acaroglu (2010). Azimi et al. (2010) employed fuzzy logic modelling to predict the blastability designation of rock masses. A fuzzy model was used by Rezaei et al. (2011) for the prediction of flyrock in surface mining. A new fuzzy model to predict the burden from geomechanical properties of rock was developed by Monjezi and Rezaei (2011). Yari et al. (2016) used an approach to the evaluation and classification of dimensional stone quarries with an emphasis on safety parameters. Ooriad et al. (2017) developed a novel model for mining method selection in a fuzzy environment. Najafi and Rafiee (2019) developed a new index for methane drainageability of a coal seam using the fuzzy rock engineering system. These studies show good performance of the applications of fuzzy modelling in the field of rock engineering.

\section{Prediction of geotechnical risks, using fuzzy logic modelling}

In the defined fuzzy logic model, by considering input and output parameters chosen and their behaviour, linear membership functions (triangular or trapezoidal) were

Table 3: Input parameters in the fuzzy logic modelling

\begin{tabular}{|l|l|l|l|}
\hline Parameter & Symbol & Parameter & Symbol \\
\hline $\begin{array}{l}\text { Rock quality } \\
\text { designation }\end{array}$ & RQD & Karstic index & KI \\
\hline $\begin{array}{l}\text { Uniaxial } \\
\text { compressive } \\
\text { strength }\end{array}$ & UCS & Quartz contents & QC \\
\hline Joint condition & $\mathrm{J}_{\mathrm{c}}$ & $\begin{array}{l}\text { Width of crushed } \\
\text { zone }\end{array}$ & $\mathrm{CZ}$ \\
\hline Joint orientation & $\mathrm{J}_{\mathrm{o}}$ & Clay mineral & $\mathrm{CM}$ \\
\hline $\begin{array}{l}\text { Groundwater } \\
\text { inflow }\end{array}$ & $\mathrm{GW}$ & & \\
\hline $\begin{array}{l}\text { Hydrogen } \\
\text { sulfide }\end{array}$ & $\mathrm{H}_{2} \mathrm{~S}$ & & \\
\hline Methane & $\mathrm{CH}_{4}$ & & - \\
\hline Squeezing & $\mathrm{SQ}$ & - & \\
\hline
\end{tabular}

selected to define membership functions. Moreover, for the fuzzy inference system, the Mamdani was selected because most of the geological processes are defined with linguistic variables or simple vague predicates and the Mamdani inference system is one of the most common algorithms used in geological problems (Acaroglu et al., 2008). Also, as COA is the most widely used, it was selected as a defuzzification method.

\subsection{Input and output parameters}

In defining the new fuzzy model, based on the reviewing TBM geotechnical risk assessment and performances in hard ground conditions and published literature (Barton, 1999, 2000; Khademi Hamidi et al., 2010c; Anagnostou and Kovári, 1996; Barla and Pelizza, 2000; Barla, 2001; Dalgic, 2003; Shang et al., 2004; Farrokh et al., 2006; Ramoni and Anagnostou, 2010; Jung et al., 2011), 12 input parameters were selected (see Table 3). These are the most important and obtainable parameters that may directly represent a hazard scenario occurrence (for instance: squeezing and gas emission) or indirectly affect a hazard scenario occurrence (for example RQD and joints orientation).

In parameters involved in modelling, components of RMR such as RQD, UCS, joint condition, joint orientation, and water inflow are preferred instead of RMR as they describe other issues of risk raised as well as instability as a hazard. The output parameter is the Risk Level (RL). The level of risk is classified into five categories (see Table 4). These categories include: low (negligible), with little consequence on the tunnel; low-medium (marginal), with minor damage to the tunnel and repairing with routine maintenance; medium (serious), with some environmental impact affecting the program or some delay or damage to the tunnel; medium-high (critical), with major environmental impact affecting the program or major delay or damage to the tunnel, and finally high (catastrophic), with total loss of a section of the tunnel, many difficulties, and a long delay.

In fuzzy modelling, to reduce the number of rules, input parameters are categorized into five groups and multi-stage fuzzy modelling is carried out using a MATLAB environment. Input and output parameters and the relevant groups and the fuzzy structure of multi-stage fuzzy modelling are shown in Figure 2.

In the input parameters, RQD, Jo, and Jc are categorized as Rock Mass Structure (RMS). RQD describes the fracturing degree of the rock mass. It is one of the most important components of RMR, which has a significant role in the excavation stand-up time, indicated by RMR

Table 4: Classification of the risk level [modified after Benardos and Kaliampakos (2004)]

\begin{tabular}{|l|c|c|c|c|c|}
\hline Description of Risk & Low & Low-Medium & Medium & Medium-High & High \\
\hline Category & I & II & III & IV & V \\
\hline Risk level & $0-20$ & $20-40$ & $40-60$ & $60-80$ & $80-100$ \\
\hline
\end{tabular}




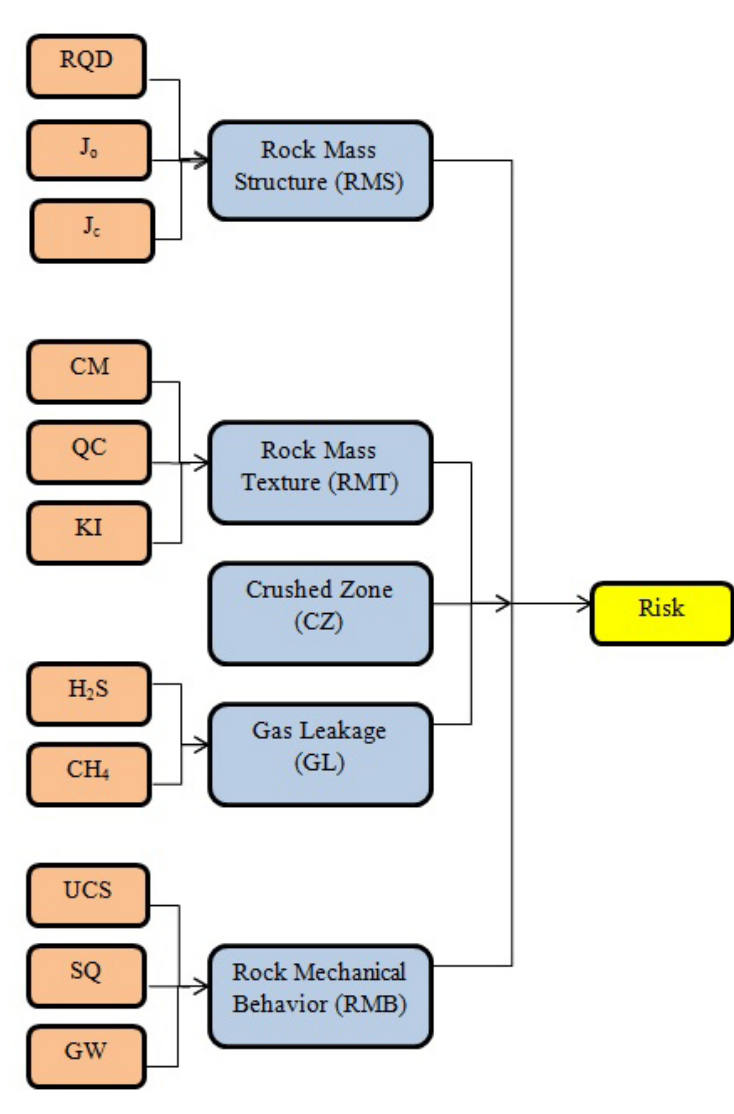

a

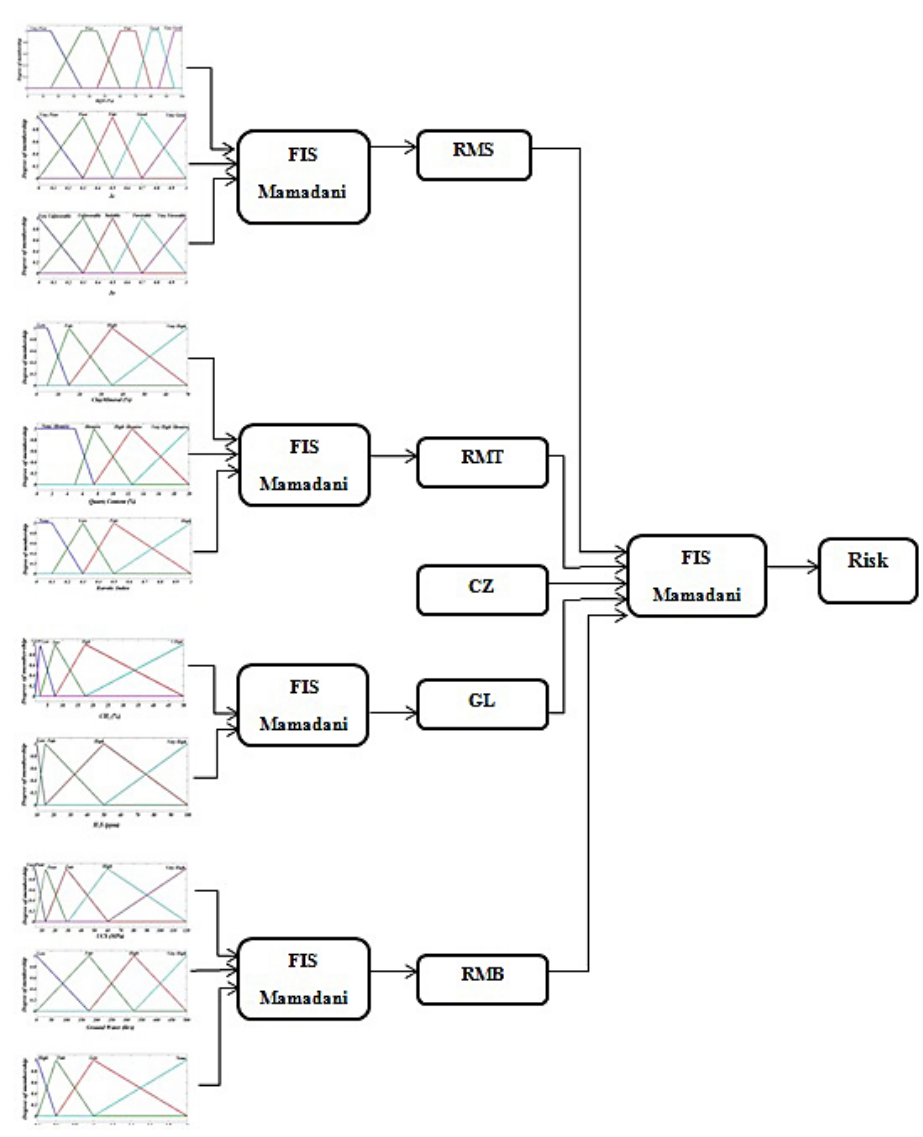

b

Figure 2: a: Input and output parameters and the relevant groups; b: Fuzzy structure of multi-stage fuzzy modelling.

(Goodman, 1989). On the other hand, rocks with low RQD cause problems during TBM gripping, putting excavation at risk and causing a decrease in the advance rate.

The orientation of joints relative to the tunnel axis influences the chipping behaviour of rocks during the excavation by TBM. Based on (Bieniawski, 1984, 1989 and Table 5), the orientation of joints perpendicular to the tunnel axis is the most favorable for TBM tunnelling.

The joint condition significantly influences excavation stability. It also affects the gripping of TBM (DAUB, 1997). The total performance of TBM in joints with very rough surfaces of a limited extent and a hard wall are much better than open joints filled with more than five $\mathrm{mm}$ of the gouge, or open more than five $\mathrm{mm}$, or joints which extend more than several meters.

The fuzzy structure of RMS and also the membership functions of RQD, Jo, Jc, and RMS are shown in Figure 3. Membership functions of RQD and Jc are defined based on the work carried out by Bieniawskiin 1984 . According to Table 5, Jo depends on the angle between the tunnel axis and dip direction $(\alpha)$ and also dip angle $(\gamma)$ and can be defined by a fuzzy system. The fuzzy structure of Jo and also, the membership functions of $\alpha$ and $\gamma$ are shown in Figure 3.

A total of seven and 125 fuzzy if-then rules are used for Jo and RMS respectively. The fuzzy if-then rules of
Table 5: The effect of discontinuity strike and dip orientation in tunnelling (Bieniawski, 1989)

\begin{tabular}{|c|c|c|c|}
\hline \multicolumn{2}{|c|}{$\begin{array}{c}\text { Strike perpendicular } \\
\text { to tunnel axis }\end{array}$} & \multicolumn{2}{c|}{$\begin{array}{c}\text { Strike parallel } \\
\text { to tunnel axis }\end{array}$} \\
\hline \multicolumn{2}{|c|}{ Drive with dip } & \multicolumn{2}{|c|}{ Drive against dip } \\
\hline Dip $45^{\circ}-90^{\circ}$ & Dip $20^{\circ}-45^{\circ}$ & Dip $45^{\circ}-90^{\circ}$ & Dip $20^{\circ}-45^{\circ}$ \\
\hline $\begin{array}{c}\text { Very } \\
\text { favorable }\end{array}$ & Favorable & Fair & Unfavorable \\
\hline $\begin{array}{c}\text { Strike parallel to tunnel } \\
\text { axis }\end{array}$ & \multicolumn{2}{|c|}{ Irrespective of strike } \\
\hline Dip $20^{\circ}-45^{\circ}$ & Dip $45^{\circ}-90^{\circ}$ & \multicolumn{2}{|c|}{ Dip $0^{\circ}-20^{\circ}$} \\
\hline Fair & $\begin{array}{c}\text { Very } \\
\text { unfavorable }\end{array}$ & \multicolumn{2}{|c|}{ Fair } \\
\hline
\end{tabular}

Jo and samples of the fuzzy if-then rules for RMS are shown in Figure 4. Further, a graphical indication of the mechanism of fuzzy reasoning for RMS is illustrated in Figure 5.

In the fuzzy modelling carried out, $\mathrm{CM}, \mathrm{QC}$, and $\mathrm{KI}$ are grouped as Rock Mass Texture (RMT). In the presence of water and rocks containing clay minerals, for instance, shale and marl, sticky conditions may have occurred, which in return cause delays and sometimes cutterhead trapping. In the case of facing abrasive rocks, which are identified by their quartz contents, wearing 


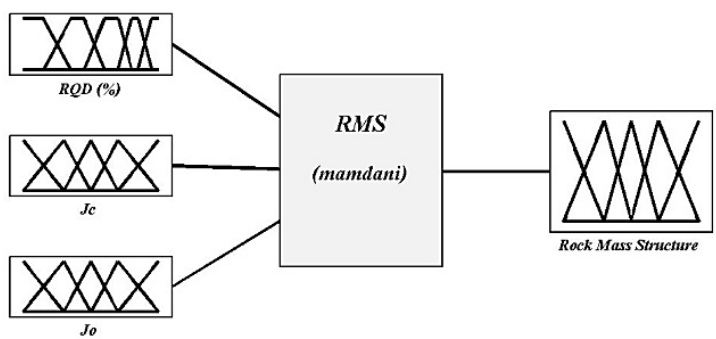

a

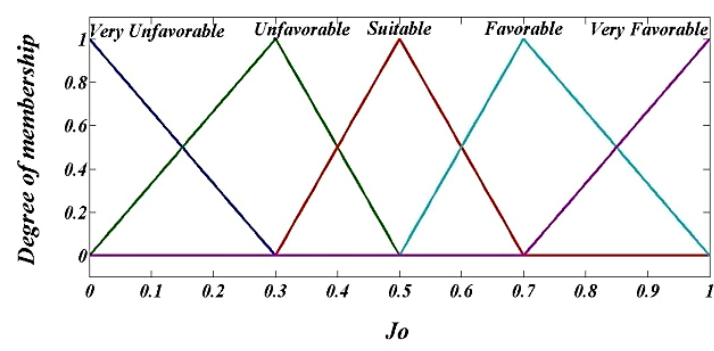

$\mathrm{c}$
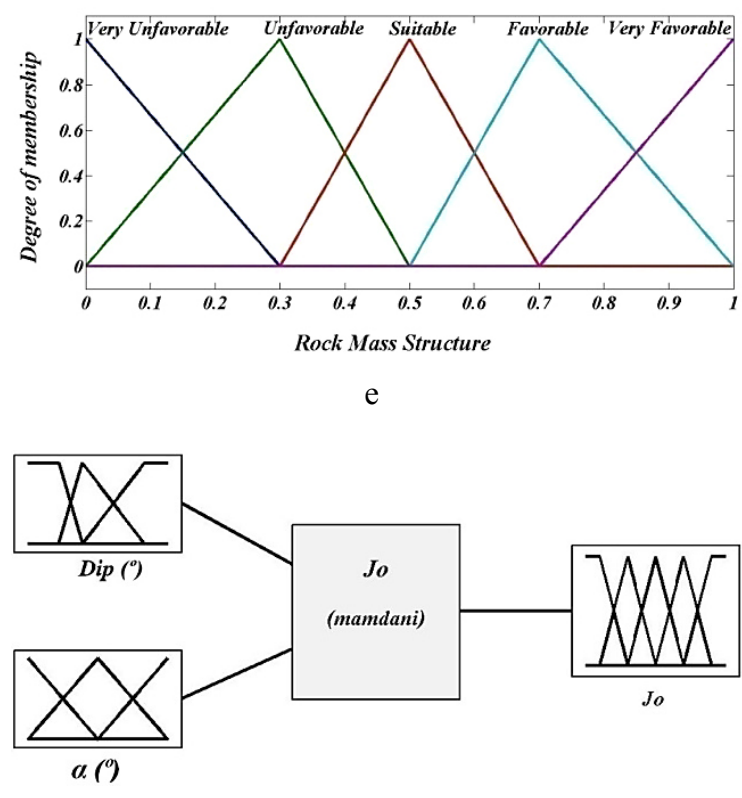

g

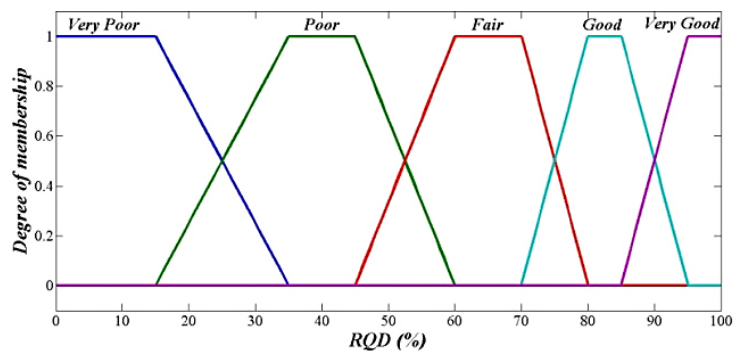

$\mathrm{b}$

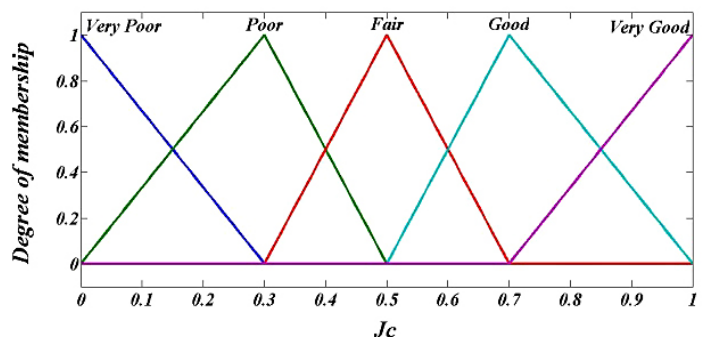

d

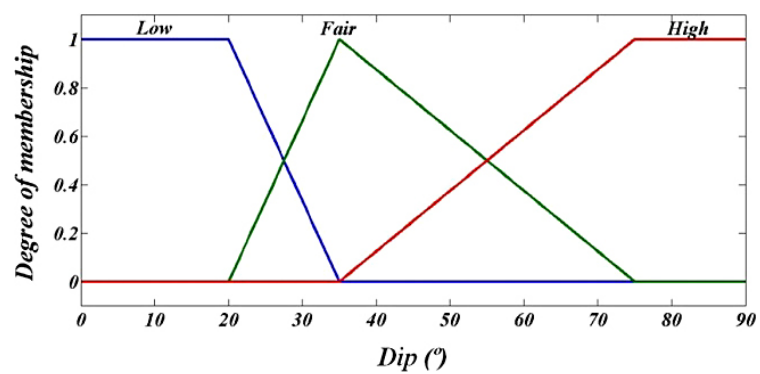

f

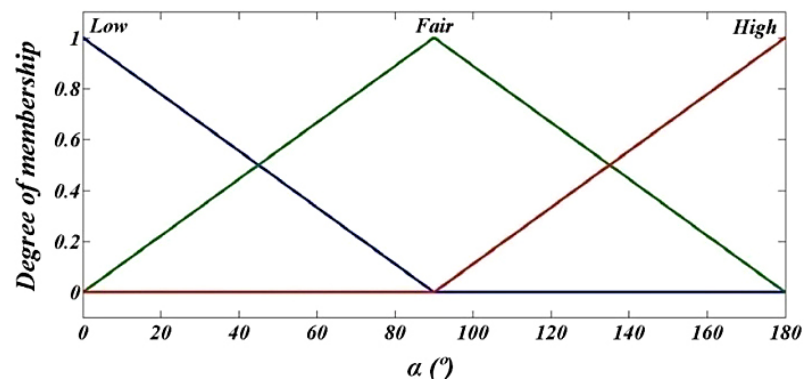

$\mathrm{h}$

Figure 3: a: Fuzzy structure of RMS; b: Membership functions of RQD; c: Membership functions of $\mathrm{J}_{0}$; d: Membership functions of Jc; e: Membership functions of RMS; f: Membership functions of dip angle $(\gamma)$; $\mathrm{g}$ : fuzzy structure of $\mathrm{J}_{\mathrm{o}}$; h: Membership functions of $\alpha$.

of cutters might occur, causing significant delays to tunnelling.

The occurrence of karstic zones through the tunnel alignment results in decreasing rock strength, which in turn reduces the load-bearing of rock. In this case, it is impossible or difficult to use the benefits of gripping, while a double-shield TBM is used. On the other hand, in the case of having gases such as $\mathrm{CH}_{4}$ and $\mathrm{H}_{2} \mathrm{~S}$, karstic zones facilitate the leakage of such gases into the tunnel, which raises the TBM tunnelling risks (Marinos, 2001). Moreover, facing karstic holes in the tunnel floor may cause the sinking of TBM. For the occurrence of a karstic zone, it is required to have carbonate rocks, joints, and flow of water. In the Zagros tunnel, in some zones, the need for the occurrence of karstic zones are met.

The structure of fuzzy modelling for RMT and also the membership functions for $\mathrm{CM}, \mathrm{QC}, \mathrm{KI}$, and RMT are revealed in Figure 6. In total, 64 fuzzy if-then rules were utilized for RMT.

The width of the $\mathrm{CZ}$, relevant water and mud inflow, squeezing, and RQD affect the main hazard scenarios (sinking TBM, face and walls instability, and the level of squeezing) corresponding to encountering fault zones. With a wider crushed zone, lower RQD, and in the pres- 


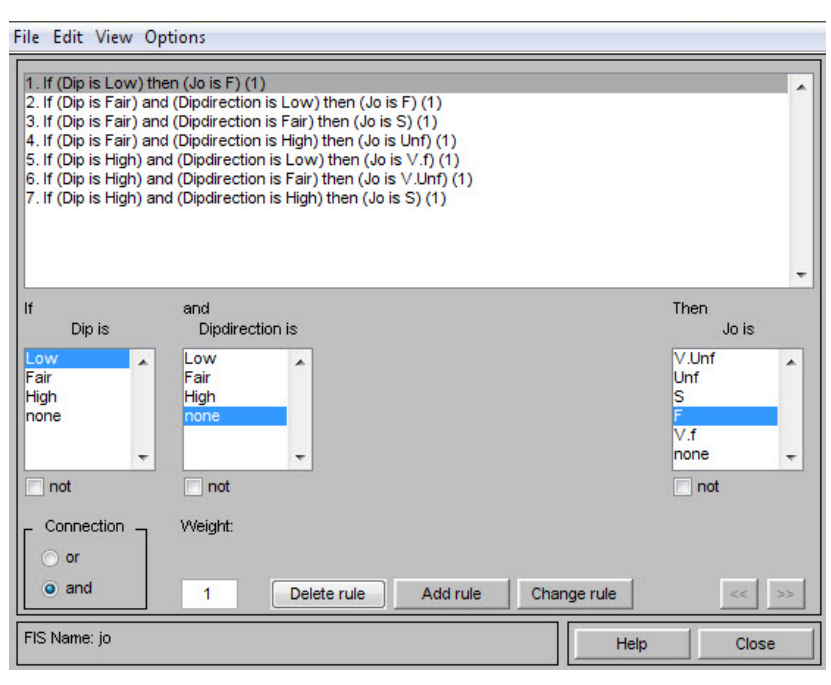

a

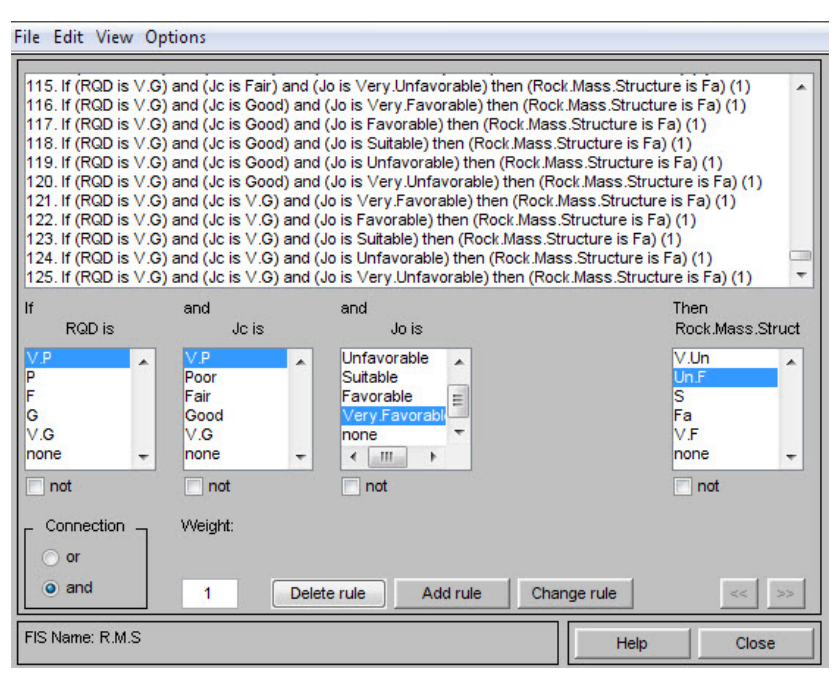

b

Figure 4: a: Fuzzy if-then rules for $J_{\mathrm{o}}$; b: Fuzzy if-then rules samples of RMS.

ence of high-water inflow, a higher degree of risk is expected, which in return causes jamming of TBM, delay, and economic loss. The effects of RQD and GW are already considered in the RMS and RMB respectively. Figure 7 shows the membership functions of the $\mathrm{CZ}$.

Emission of gases such as hydrogen sulfide $\left(\mathrm{H}_{2} \mathrm{~S}\right)$, methane $\left(\mathrm{CH}_{4}\right)$, hydrogen cyanide $(\mathrm{HCN})$, and carbon monoxide (CO) into the tunnel might cause safety concerns such as damage due to explosion, human loss, and respiratory problems as well as corrosion damage, all which result in delays in tunnelling.

In most cases, $\mathrm{CH}_{4}$ and $\mathrm{H}_{2} \mathrm{~S}$ are in the center of concern. $\mathrm{CH}_{4}$ is an explosive and flammable gas, lighter than air and odorless. The Lower Explosive Limit (LEL) and Upper Explosive Limit (UEL) for $\mathrm{CH}_{4}$ are 5\% and 15\% respectively (Industrial Training Branch of the National Coal Board, 1981). $\mathrm{H}_{2} \mathrm{~S}$ is a colorless and toxic gas with LEL and UEL of $4 \%$ and $44 \%$ respectively. It is slightly heavier than air with a strong smell of rotten eggs. $\mathrm{H}_{2} \mathrm{~S}$ dissolves in water, resulting in a weakly acidic solution. The main hazards are related to its toxic effect and corrosive property to metals (Industrial Training Branch of the National Coal Board, 1981).

A fuzzy structure, denoted by Gas Leakage (GL), with $\mathrm{CH}_{4}$ and $\mathrm{H}_{2} \mathrm{~S}$ as input parameters and GL as an output parameter, is defined to consider the effects of both gases in the fuzzy modelling of risk assessment. A fuzzy structure for GL and membership functions of $\mathrm{CH}_{4}, \mathrm{H}_{2} \mathrm{~S}$, and GL are shown in Figure 8. A total of 20 fuzzy ifthen rules were used for GL.

UCS, SQ, and GW are clustered as Rock Mechanical Behaviour (RMB) in the fuzzy modelling of risk assessment. UCS shows the compressive strength of intact rocks and also has significant effects on RMR and its associated stability (Goodman, 1989). Moreover, rocks with very high UCS cause high wear and tear of cutters as well as a considerable reduction in penetration rate. Also, in rocks with low UCS, gripping problems might occur.

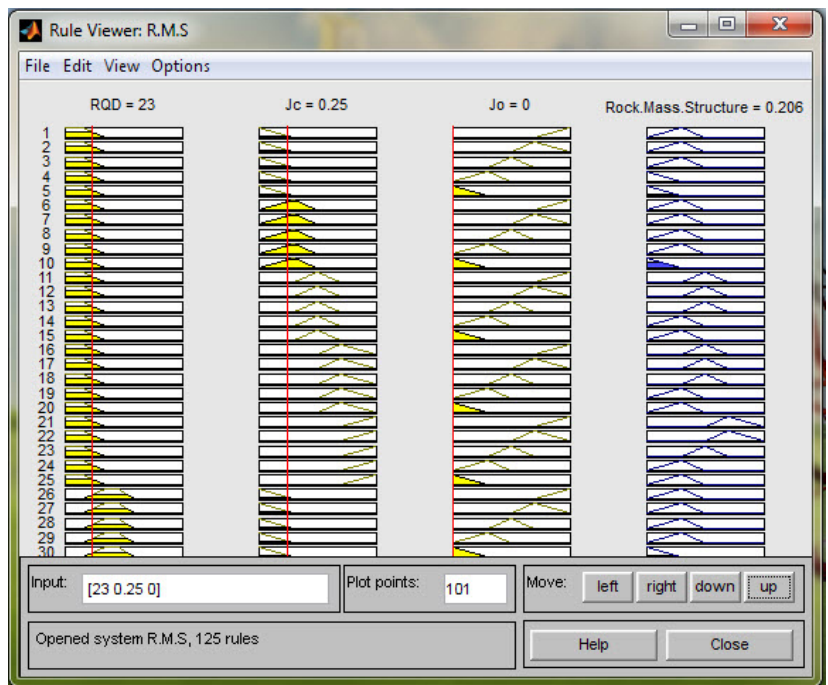

Figure 5: Fuzzy reasoning mechanism for RMS, a graphical indication.

Ground squeezing might cause inadmissible deformations of a tunnel, possible damage to a support system or in the case of mechanized excavation, a sticking cutter head or jamming of the shield, which immobilizes the TBM. Even in the case of facing a frequent squeezing condition in the tunnel, it might result in the cancellation of the TBM drive (Ramoni and Anagnostou, 2010). The ground squeezing occurrence depends on factors such as poor ground condition (rock quality), high overburden, the presence of water, the properties of rocks, and high stress. Different approaches were proposed by studies worldwide such as Jethwa et al., 1984; Singh et al., 1992; Aydan et al., 1996; Goel et al., 1995; Hoek and Marinos, 2000 to identify squeezing rock conditions. In this research, the Jethwa et al., 1984 approach is applied to obtain the squeezing potential in different zones of the Zagros tunnel. In this approach, the squeezing coefficient is defined and the potential of 


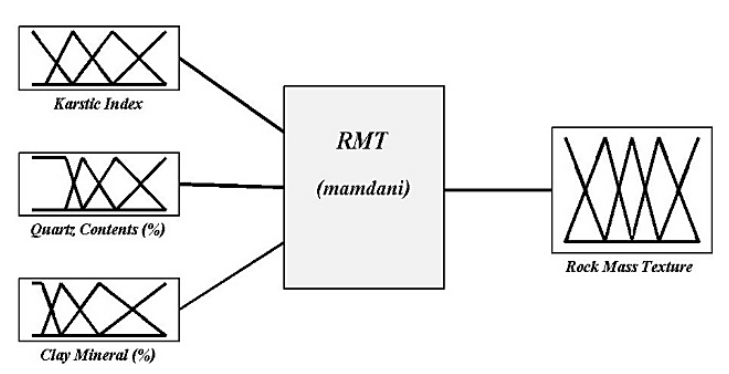

$\mathrm{a}$

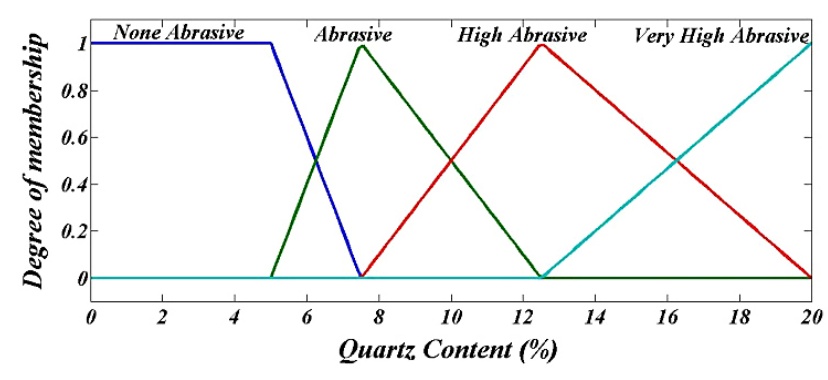

$\mathrm{c}$

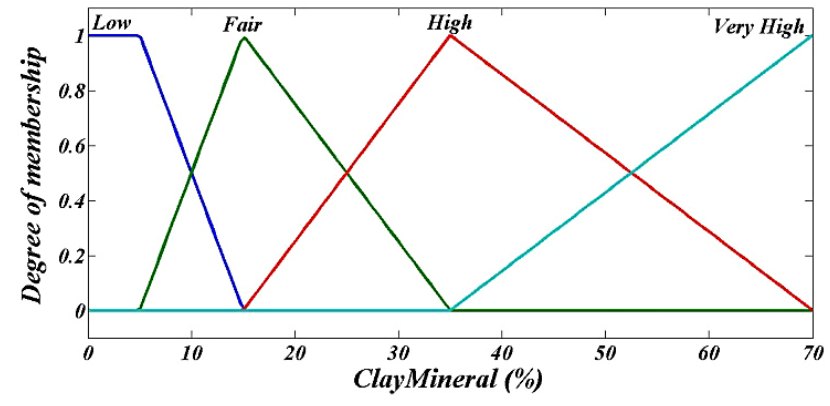

$\mathrm{b}$

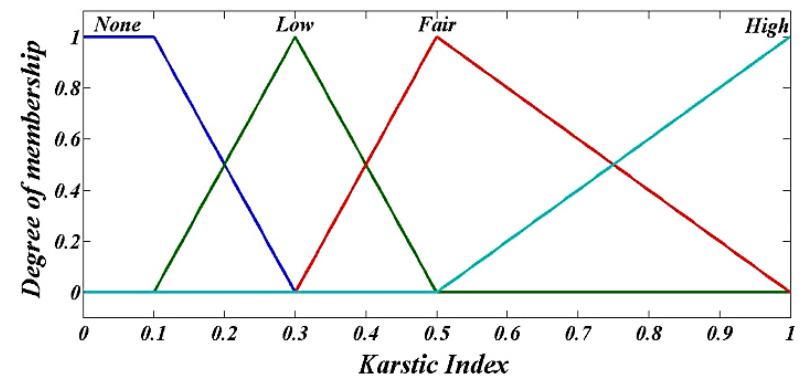

d

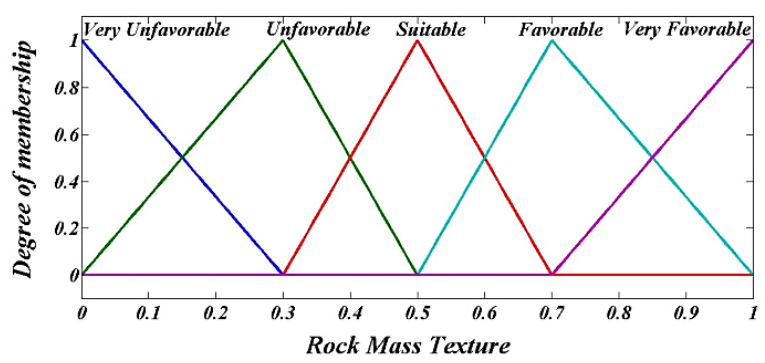

e

Figure 6: The structure of fuzzy modelling for RMT; b: Membership functions of CM; c: Membership functions of QC; $\mathrm{d}$ : Membership functions of KI; e: Membership functions of RMT.

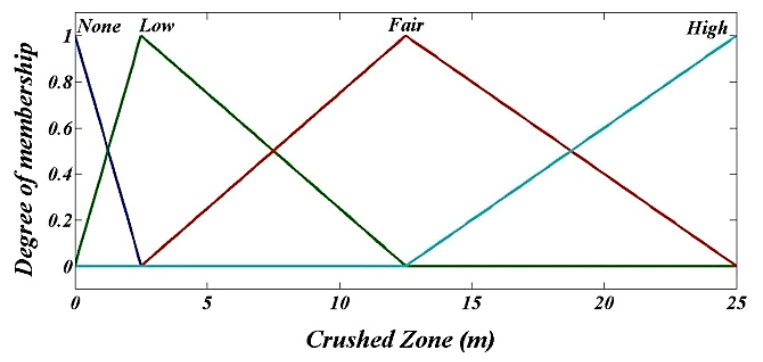

Figure 7: CZ membership functions

squeezing categorized into four groups as revealed in Table 6.

Rock mass behaviour can be influenced strongly by groundwater (Goodman, 1989). Also, the pore pressure in rocks depends on the level of groundwater. A higher groundwater level means more pore pressure, resulting in decreasing stability, and in the case of high permeability and the presence of joints, increasing in water inflow. A high inflow of water (lit/s/10 m) causes delays and possible damage.
The fuzzy structure of RMB as well as membership functions of UCS, SQ, GW, and RMB are illustrated in Figure 9. A sum of 80 fuzzy if-then rules were utilized for RMB.

The structure of fuzzy modelling and membership functions of the level of risk for TBM geotechnical risk modelling are shown in Figure 10. In Figure 10 a, RMS, RMT, RMB, GL, and CZ are input parameters and the level of geotechnical risk is the output parameter. A total of 1575 fuzzy if-then rules were used in the defined fuzzy system.

\subsection{Validation of the fuzzy logic model for geotechnical risk prediction}

As risk has a descriptive nature, the level of risk encountered during tunnelling excavation cannot be measured in the field. Therefore, the level of risk predicted through fuzzy logic modelling cannot be validated directly against real data from the field. To show the validity of the proposed model, two approaches were applied. In the first approach, the field data from 58 geological 

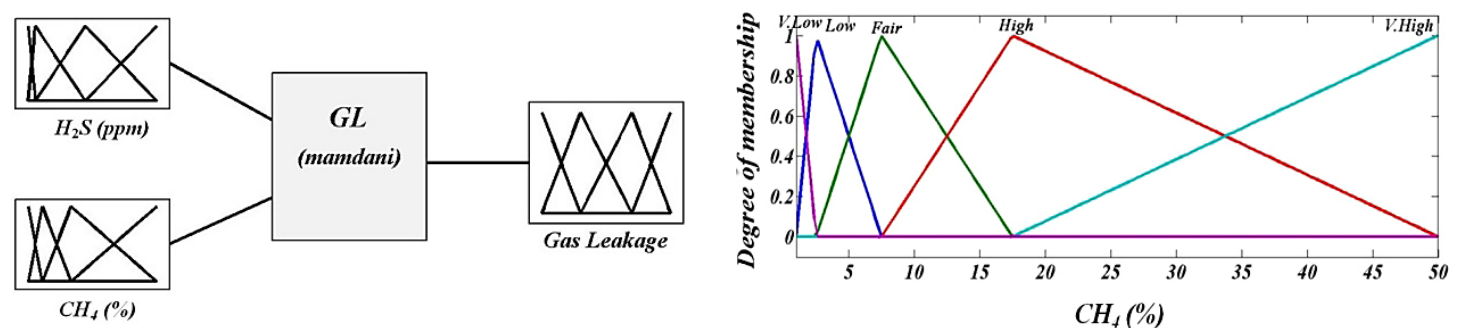

a

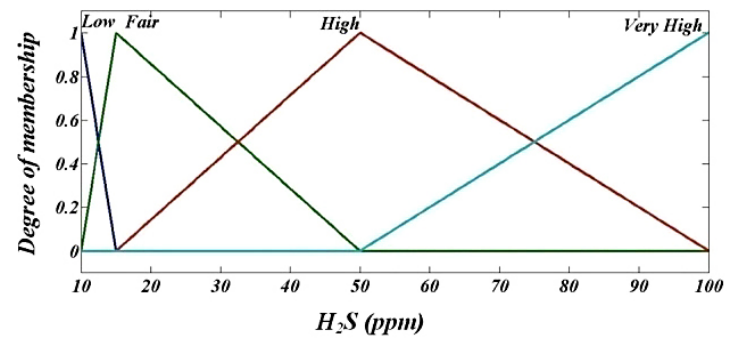

c

b

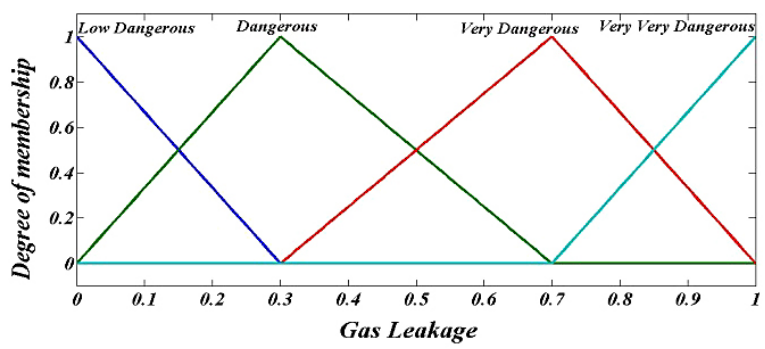

d

Figure 8: a: A fuzzy structure for GL; b: Membership functions of $\mathrm{CH}_{4}$; c: Membership functions of $\mathrm{H}_{2} \mathrm{~S}$; d: Membership functions of GL

zones in section two of the Zagros tunnel, Iran were used in the fuzzy model and the corresponding risk level for each zone was obtained (see Figure 11) and categorized based on Table 4. Then, the level of risk obtained for each zone was compared with possible problems and
Table 6: Classification of squeezing (Jethwa et al., 1984)

\begin{tabular}{|l|c|c|c|c|}
\hline $\begin{array}{l}\text { Coefficient } \\
\text { of squeezing }\end{array}$ & $>\mathbf{2}$ & $\mathbf{0 . 8 - 2}$ & $\mathbf{0 . 4 - 0 . 8}$ & $<\mathbf{0 . 4}$ \\
\hline Description & Non-squeezing & Low & Medium & High \\
\hline
\end{tabular}

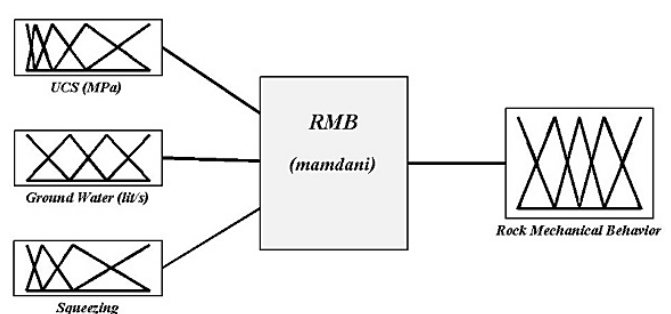

a

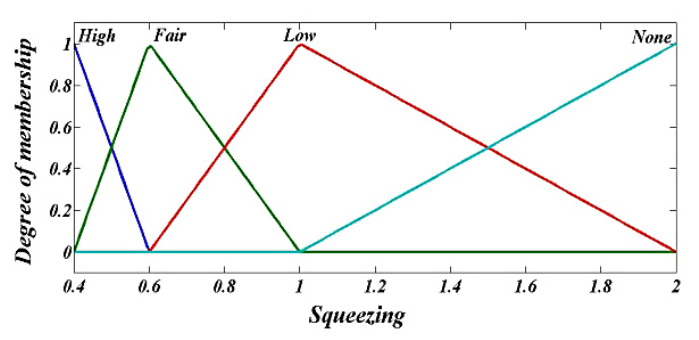

$\mathrm{c}$

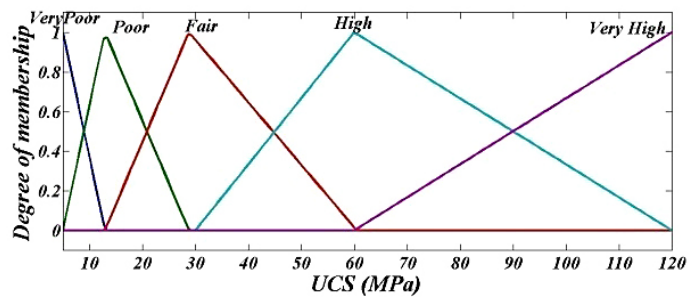

b

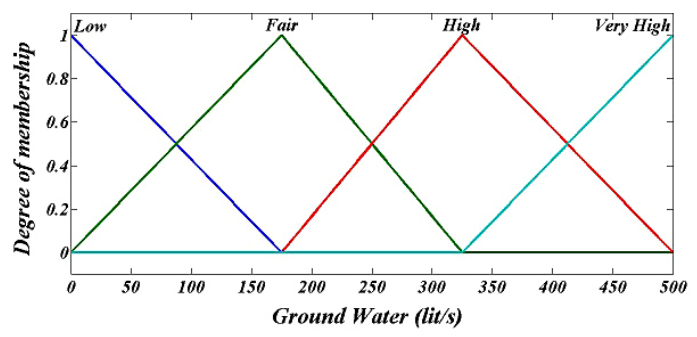

d

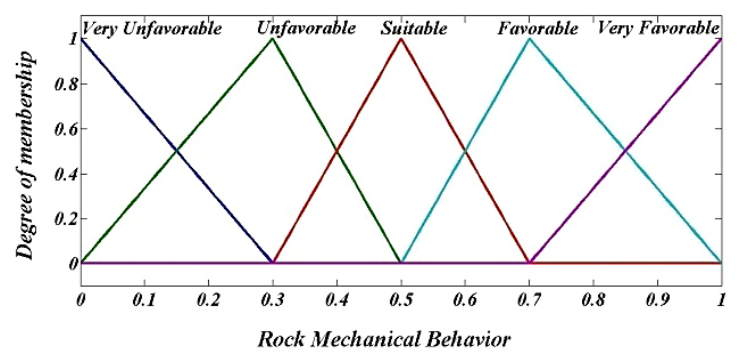

e

Figure 9: a: Fuzzy structure of RMB; b: Membership functions of UCS; c: Membership functions of SQ; $\mathrm{d}$ : Membership functions of GW; e: Membership functions of RMB 


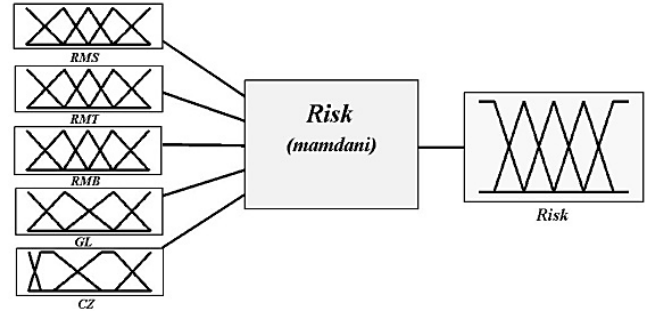

a

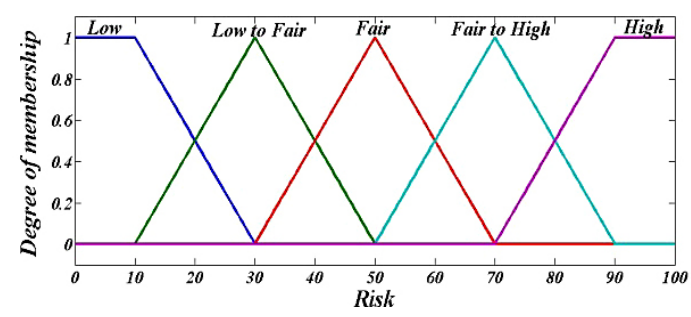

b

Figure 1o: a: The structure of fuzzy modelling for TBM geotechnical risk; b: Membership functions of risk

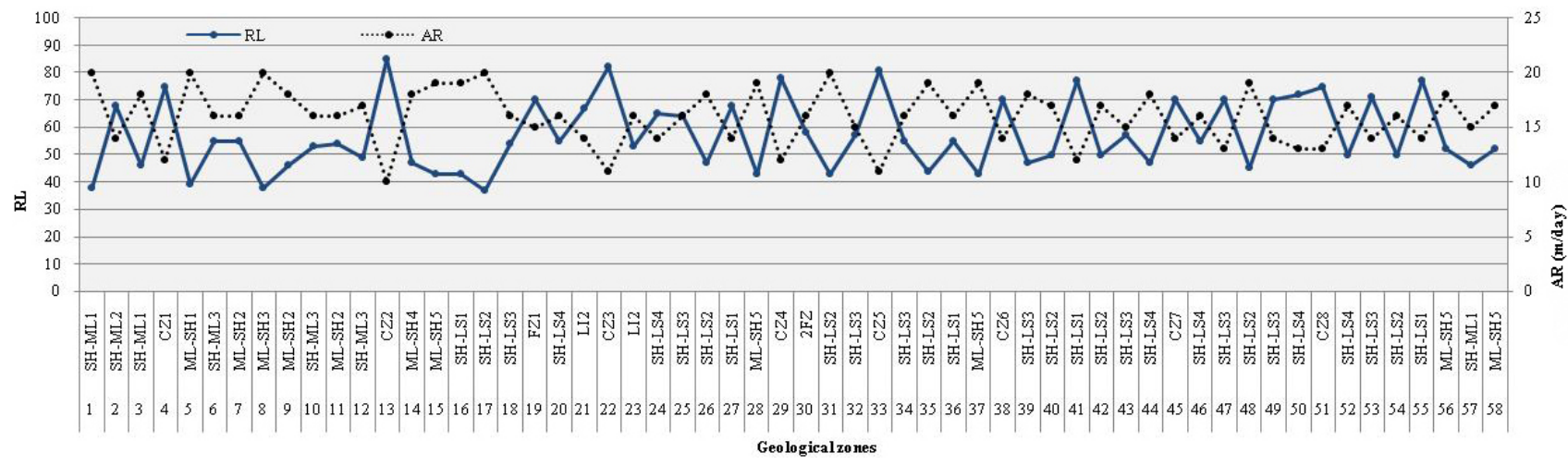

Figure 11: Changes in the average advance rate with the level of risk in the individual zones, section two of the Zagros tunnel

delays observed during the excavation of the corresponding zone.

It can be seen in Figure 11 that the levels of risk predicted vary from 37 for zone SH-LS2 to 85 for zone CZ2. In zone CZ2 with a risk level of 85 , based on the field observations, this high level of risk is due to the high flow of water, low RQD, and a crushed zone with a width of more than $100 \mathrm{~m}$. In this zone, due to the instability of the tunnel face and walls, some serious problems and delays occurred during excavation. Also, CZ3 was another problematic zone with a risk level of 82 , which has been confirmed by field observations. The risk in this zone is due to face and wall instability as well as $\mathrm{H}_{2} \mathrm{~S}$ and $\mathrm{CH}_{4}$ emissions, which are present in the inter-layers during tunnel excavation near oil fields. It is found that in most of the zones, the field observations experienced in each individual zone have a good agreement with the risk level predicted through the fuzzy logic modelling.

In the second approach, the agreement between the level of risk and the average AR measured for each zone was explored, as illustrated in Figure 11. It can be seen in this figure, as expected, in zones with a higher level of risks, fewer advance rates were experienced and for all examined zones, the level of risks correlates reasonably well with the advance rates measured. Furthermore, the correlation between the level of risks and the average advance rates achieved in 58 zones was determined, as shown in Figure 12.

As it is evident from Figure 12, a high determination coefficient $\left(\mathrm{R}^{2}\right)$ of 0.91 between the level of risks and the

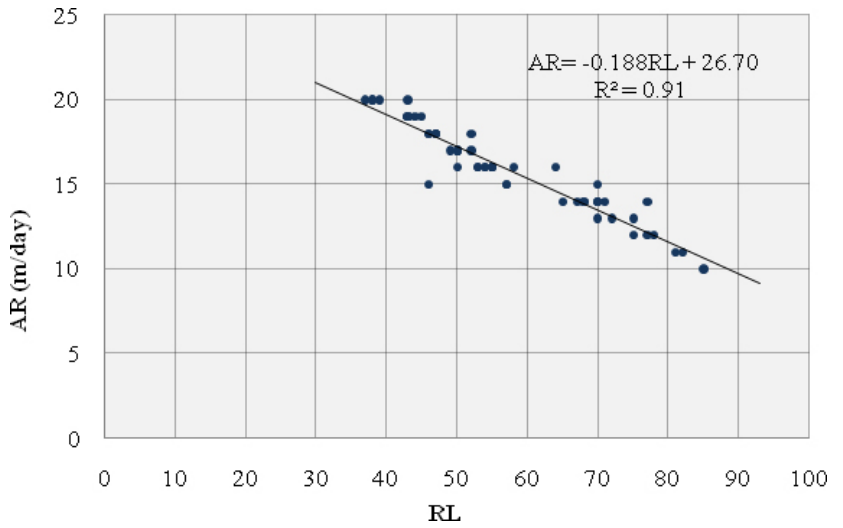

Figure 12: Correlation between the level of risk and the average advance rate, section two of the Zagros tunnel

average advance rates once again indicates the validity of the developed model.

\section{Using geotechnical risks to predict the advance rate}

Advance rate variation with the risk level (see Figure 11) suggests a strong correlation between the advance rate and the risk level, as shown in Figure 12. This leads to the development of a new model for advance rate prediction, using the levels of geotechnical risks. Out of the data for 58 zones, the data for 48 zones were selected randomly and linear regression analysis with the RL as an independent variable and the AR as a dependent vari- 


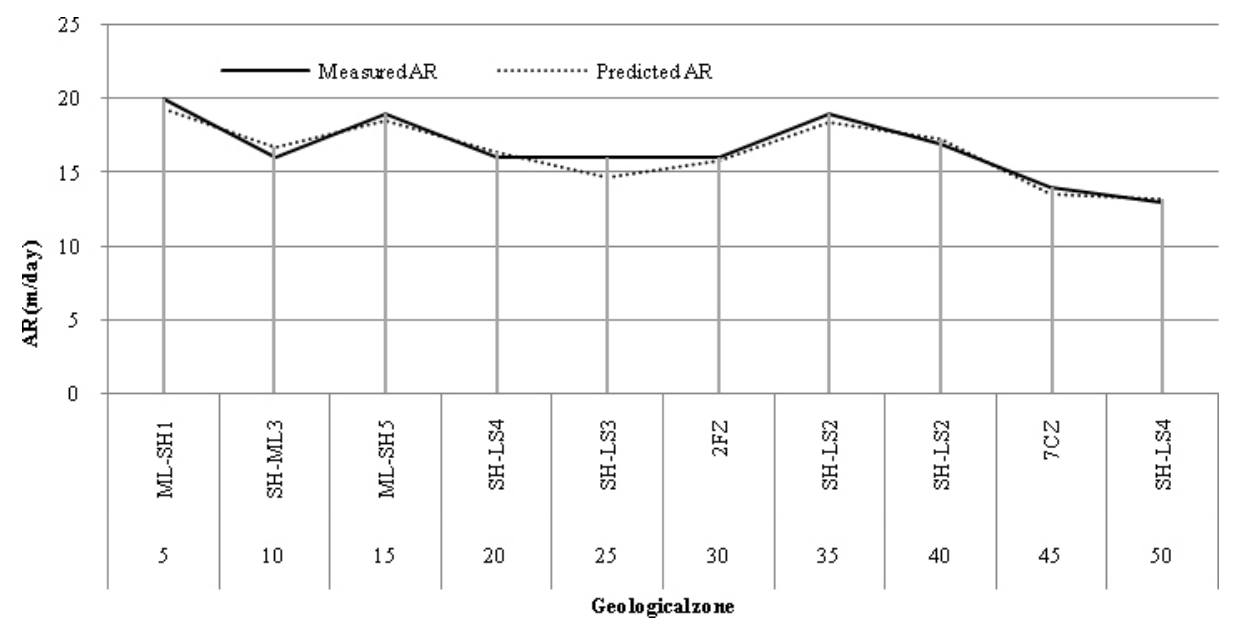

Figure 13: Comparison between measured and predicted advance rates for 10 sets of data.

able was carried out and the predictive model with $\mathrm{R}^{2}$ of 0.91 is presented in Equation 3.

$$
A R=26.70-0.188(R L)
$$

Where:

$A R$ - Advance Rate of TBM (m/day),

$R L$ - Risk Level.

Performance evaluation of this model was carried out by 10 sets of data (data from 10 randomly selected zones out of 58 zones), which were not used in the modelling. A comparison was made between the predicted and measured advance rate values for 10 zones, which are shown in Figure 13. For these zones, a high $\mathrm{R}^{2}$ of 0.93 is obtained as revealed in Figure 14.

Moreover, RMSE (Equation 4) and VAF (Equation 5) were used as other indices for further evaluation of the model performance, where the VAF index shows the degree of difference between the variances of the predicted and measured parameters and the RMSE index is a measure of the bias between the measured and predicted parameters. The VAF close to $100 \%$ indicates small variability and better prediction capability of the defined model. On the other hand, lower RMSE shows the better performance of a model.

$$
\begin{gathered}
\operatorname{RMSE}(x)=\sqrt{\frac{1}{n} \sum_{i=1}^{n}\left(x_{\text {imeas }}-x_{\text {ipred }}\right)^{2}} \\
V A F=100\left(1-\frac{\operatorname{var}\left(x_{\text {imeas }}-x_{\text {ipred }}\right)}{\operatorname{var}\left(x_{\text {imeas }}\right)}\right.
\end{gathered}
$$

Where:

Var - variance

$x_{\text {imeas }}-$ the $\mathrm{i}^{\text {th }}$ element measured,

$x_{i p r e d}-$ the $\mathrm{i}^{\text {th }}$ element predicted,

$n$ - Number of datasets.

For 10 zones selected, RMSE of 0.62 and VAF of 97.51 were obtained that with $\mathrm{R}^{2}=0.93$ confirm the good

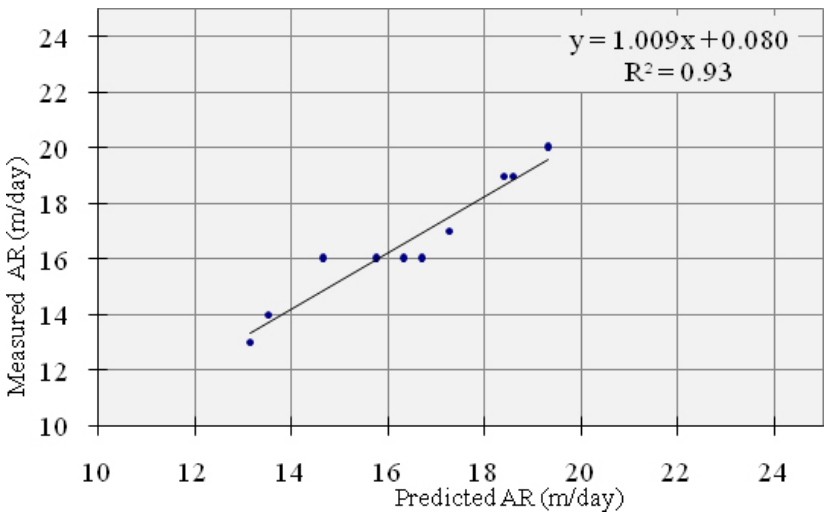

Figure 14: Correlation between measured and predicted advance rates for 10 sets of data.

performance of the model proposed for the advance rate prediction.

\section{Conclusions}

Before starting a TBM tunnelling project, it is necessary to carry out a risk analysis program. In particular, geotechnical risk analyses are of prime importance as they are the main source of risks imposed on the tunnelling process. In this research, by considering the most important and effective parameters in geotechnical hazard scenario occurrences in rock TBM tunnelling and applying fuzzy logic modelling, the level of geotechnical risks can be estimated. Furthermore, using data collected from 58 geological zones of section two of the Zagros tunnel, the risk level for each geological zone was determined and a model for the prediction of advance rate, using the risk levels was presented.

The obtained results showed that with the field data from section two of the Zagros tunnel, there is considerable consistency between the level of risk estimated through modelling and the risk observed in the field. Also, the high $\mathrm{R}^{2}$ of 0.91 between the level of risk and the measured average advance rate achieved in each 
zone shows the ability of the model proposed to predict the risk level in rock TBM tunnelling. Moreover, the new predictive model for advance rate prediction with $\mathrm{R}^{2}=0.93, \mathrm{RMSE}=0.62$, and $\mathrm{VAF}=97.51$ between the measured and predicted advance rates has very good efficiency and may be applied for advance rate prediction, using the risk levels estimated.

The proposed fuzzy model for the estimation of the risk level of rock TBM tunnelling is not site dependent and may be used for any tunnel project with the same input parameters. However, it should be noted that the proposed model for advance rate prediction was developed, using the limited sets of data from section two of the Zagros tunnel. It is obvious that this model cannot be generalized for all the TBM projects. However, more development of this model is possible if more data is available.

\section{References}

Acaroglu, O. (2011): Prediction of thrust and torque requirements of TBMs with fuzzy logic models. Tunnelling and Underground Space Technology, 26, 267-275. doi: 10.1016/j.tust.2010.10.001.

Acaroglu, O., Ozdemir, L. and Asbury, B. (2008): A fuzzy logic model to predict specific energy requirement for TBM performance prediction. Tunnelling and Underground Space Technology, 23, 5,600-608. doi: 10.1016/j. tust.2007.11.003.

Alvarez Grima, M. (2000): Nero-fuzzy Modeling in Engineering Geology. A.A Balkema, Rotterdam, 224 p.

Alvarez Grima, M. and Babuška, R. (1999): Fuzzy model for the prediction of unconfined compressive strength of rock samples. International Journal of Rock Mechanics and Mining Sciences, 36, 3, 339-349. doi: 10.1016/S01489062(99)00007-8.

Alvarez Grima, M., Bruines, P. A. and Verhoef, P. N. W. (2000): Modelling tunnel boring machine performance by neuro-fuzzy methods. Tunnelling and Underground Space Technology, 15, 3, 259-269. doi: 10.1016/S0886-7798(00) 00055-9.

Alvarez Grima, M. and Verhoef, P. N. W. (1999): Forecasting rock trencher performance using fuzzy logic. International Journal of Rock Mechanics and Mining Sciences, 36, 4, 413-432. doi: 10.1016/S0148-9062(99)00025-X.

Anagnostou, G. and Kovári, K. (1996): Face stability conditions with earth-pressure-balanced shields. Tunnelling and Underground Space Technology, 11, 2, 165-173. doi: 10.1016/0886-7798(96)00017-X.

Ataei, M., Khalokakaei, R. and Hossieni, M. (2009): Determination of coal mine mechanization using fuzzy logic. Mining Science and Technology, 19, 2, 149-154. doi: 10.1016/ S1674-5264(09)60028-4.

Aydan, Ö.,Akagi, T. and Kawamoto, T. (1996): The squeezing potential of rock around tunnels. Theory and prediction with examples taken from Japan. Rock Mechanics and Rock Engineering, 29, 3, 125-143. doi: 10.1007/BF010 32650 .
Azimi, Y., Osanloo, M., Aakbarpour-Shirazi, M. and AghajaniBazzazi. (2010): Prediction of the blastability designation of rock masses using fuzzy sets. International Journal of Rock Mechanics and Mining Sciences, 47, 7, 1126-1140. doi: 10.1016/j.ijrmms.2010.06.016.

Barla, G. (2001): Tunneling under Squeezing Rock Conditions. In: Kolymbas, D. (ed.): Eurosummer-School in Tunnel Mechanics. Logos Verlag Berlin, 169-268

Barla, M. (2001), “Tunnelling under squeezing conditions”, in Kolymbas, D. (Ed.),

Euro-Summerschool on Tunnelling Mechanics, Innsbruck, Logos, Berlin, pp. 169-268.

Barla, G. and Pelizza, S. (2000): TBM Tunneling in Difficult Ground Conditions. In: ISRM International Symposium 2000. Melbourne, Australia, November 19-24, 2000.

Barton, N. (1999): TBM performance estimation in rock using Q (TBM). Tunnels and Tunnelling International, 31, 9, 30-34.

Barton N. (2000): TBM Tunneling in Jointed and Faulted Rock. A.A Balkema, Rotterdam, Netherland, 173 p.

Benardos, A. G. and Kaliampakos, D. C. (2004): A methodology for assessing geotechnical hazards for TBM tunnelling - Illustrated by the Athens Metro, Greece. International Journal of Rock Mechanics and Mining Sciences, 41, 6, 987-999. doi: 10.1016/j.ijrmms.2004.03.007.

Bieniawski, Z. T. (1984): Rock Mechanics Design in Mining and Tunneling. A.A Balkema, Rotterdam, 280 p.

Bieniawski, Z. T. (1989): Engineering rock mass classifications: a complete manual for engineers and geologists in mining, civil, and petroleum. John Wiley\& Sons, Hoboken, New Jersey, $251 \mathrm{p}$.

Cancelli, A. and Crosta, G. B. (1993): Hazard and Risk Assessment in Rockfall Prone Areas. In: Skip, B.O. (ed): Risk Reliability in Ground Engineering. Thomas Telford, London, 1993, 177-190.

Dalgic, S. (2003): Tunneling in fault zones, Tuzla tunnel, Turkey. Tunnelling and Underground Space Technology, 18, 5, 453-465. doi: 10.1016/S0886-7798(03)00045-2.

DAUB. (1997): Recommendations for Selecting and Evaluating Tunnel Boring Machines, German Tunneling Committee.

Einstein, H. H. (1996): Risk and risk analysis in rock engineering. Tunnelling and Underground Space Technology, 11, 2, 141-155. doi: 10.1016/0886-7798(96)00014-4.

Farrokh, E., Mortazavi, A. and Shamsi, G. (2006): Evaluation of ground convergence and squeezing potential in the TBM driven Ghomroud tunnel project. Tunnelling and Underground Space Technology, 21, 5, 504-510. doi: 10.1016/j.tust.2005.09.003.

Fattahi, H. and Moradi, A. (2017): Risk assessment and estimation of TBM penetration rate using RES-Based model. Geotechnical and Geological Engineering, 35, 1, 365-376. https://doi.org/10.1007/s10706-016-0111-x

Goel, R. K., Jethwa, J. L. and Paithankar, A. G. (1995): Tunnelling through the young Himalayas - A case history of the Maneri-Uttarkashi power tunnel. Engineering Geology, 39, 1-2, 31-44. doi: 10.1016/0013-7952(94)00002-J. 
Goodman, R. (1989): Introduction to Rock Mechanics. John Wiley \& Sons, Hoboken, New Jersey, 576 p.

Hoek, E. and Marinos, P. (2000): Predicting tunnel squeezing problems in weak heterogeneous rock masses. Tunnels and Tunnelling International, 32, 11, 45-51.

Hong, E. S., Lee, I. M., Shin, H. S., Nam, S. W. and Kong, J. S. (2009): Quantitative risk evaluation based on event tree analysis technique: Application to the design of shield TBM. Tunnelling and Underground Space Technology, 24, 3, 269-277. doi: 10.1016/j.tust.2008.09.004.

Hudson, J. (1992): Rock Engineering Systems, Theory and Practice. Ellis Horwood, Chichester, 196 p.

Hyun, K.C., Min, S., Choi, H., Park, J. and Lee, I.M. (2015): Risk analysis using fault-tree analysis (FTA) and analytic hierarchy process (AHP) applicable to shield TBM tunnels. Tunnelling and Underground Space Technology, 49, 121-129. https://doi.org/10.1016/j.tust.2015.04.007

Industrial Training Branch of the National Coal Board. (1981), Mine Gases, National Coal Board of USA.

Iphar, M. and Goktan, R. M. (2006): An application of fuzzy sets to the diggability index rating method for surface mine equipment selection. International Journal of Rock Mechanics and Mining Sciences, 43, 2, 253-266. doi: 10.1016 /j.ijrmms.2005.07.003.

Jethwa, J. L., Singh, B. and Singh, B. (1984): Estimation of Ultimate Rock Pressure for Tunnel Linings under Squeezing Rock Conditions, A New Approach. In: Brown, E.T., Hudson, J.A. (eds.): Design and Performance of Underground Excavations. ISRM Symposium, Cambridge, U.K., September 3-4, 1984, 231-238.

Jian, S., Lian-guo, W., Hua-lei, Z. and Yi-feng, S. (2009): Application of fuzzy neural network in predicting the risk of rock burst. Procedia Earth and Planetary Science, 1, 1, 536-543. doi: 10.1016/j.proeps.2009.09.085.

Jung, H. S., Choi, J. M., Chun, B. S., Park, J. S. and Lee, Y. J. (2011): Causes of reduction in shield TBM performance - A case study in Seoul. Tunnelling and Underground Space Technology, 26, 3,453-461. doi: 10.1016/j.tust.2011.01.001.

KhademiHamidi, J., Shahriar, K., Rezai, B., Rostami, J. and Bejari, H. (2010a): Risk assessment based selection of rock TBM for adverse geological conditions using FuzzyAHP. Bulletin of Engineering Geology and the Environment, 69, 4, 523-532. https://doi.org/10.1007/s10064009-0260-8

KhademiHamidi, J., Shahriar, K., Rezai, B, and Bejari, H. (2010b): Application of fuzzy set theory to rock engineering classification systems: An illustration of the rock mass excavability index. Rock Mechanics and Rock Engineering, 43, 3, 335-350. doi: 10.1007/s00603-009-0029-1.

KhademiHamidi, J., Shahriar, K., Rezai, B. and Rostami, J. (2010c): Performance prediction of hard rock TBM using rock mass rating (RMR) system. Tunnelling and Underground Space Technology, 25, 4, 333-345. doi: 10.1016/j. tust.2010.01.008.

Lar consulting engineers. (2004): Geotechnical Engineering Study of Zagros Long Tunnel, Lar consulting engineers, Tehran, Iran.

Marinos, P. G. (2001): Tunneling and Mining in Karsticterrane, an Engineering Challenge. In: Beck, B.F., and Her- ring, J.G. (eds.): Geotecnical and Environmental Applications of Karst Geology and Hydrology. Swets and Zeitlinger, Lisse, Louisville, United State, April 1-4, 3-16.

Monjezi, M., Rezaei, M. and YazdianVarjani, A. (2009): Prediction of rock fragmentation due to blasting in Gol-EGohar iron mine using fuzzy logic. International Journal of Rock Mechanics and Mining Sciences, 46, 8, 1273-1280. doi: 10.1016/j.ijrmms.2009.05.005.

Monjezi, M. and Rezaei, M. (2011): Developing a new fuzzy model to predict burden from rock geomechanical properties. Expert Systems with Applications, 38, 8, 9266-273. https://doi.org/10.1016/j.eswa.2011.01.029.

Moradi, M.R. and Farsangi, M.A.E. (2014): Application of the risk matrix method for geotechnical risk analysis and prediction of the advance rate in rock TBM tunneling. Rock Mechanics and Rock Engineering, 47, 1951-1960. https:// doi.org/10.1007/s00603-013-0464-x

Ooriad, F., Yari, M., Bagherpour, R. and Khoshouei, E.M. (2018): The development of a novel model for mining method selection in a fuzzy environment; case study: Tazareh coal mine, Semnan province, Iran. Rudarskogeološko-naftni zbornik (The Mining, Geological and Petroleum Engineering Bulletin), 33, 45-53.

Rafiee, R. and Najafi, M. (2019): Development of a new index for methane drainageabili y of a coal seam using the fuzzy rock engineering system. Rudarsko-geološko-naftni Zbornik (The Mining, Geological and Petroleum Engineering Bulletin), 47, 33-45. DOI: 10.17794/rgn.2019.4.4

Ramoni, M. and Anagnostou, G. (2010): Tunnel boring machines under squeezing conditions. Tunnelling and Underground Space Technology, 25, 2, 139-157. doi: 10.1016/j. tust.2009.10.003.

Rezaei, M., Monjezi, M. and YazdianVarjani, A. (2011): Development of a fuzzy model to predict flyrock in surface mining. Safety Science, 49, 2, 298-305. doi: 10.1016/j. ssci.2010.09.004.

Ross, T. (1995): Fuzzy Logic with Engineering Applications. McGraw-Hill Inc, New York, 607 p.

Saldivar-Sali, A. and Einstein, H. H. (2007): A landslide risk rating system for baguio, Philippines. Engineering Geology, 91, 2-4, 85-99. doi: 10.1016/j.enggeo.2006.11.006.

Shahriar, K., Sharifzadeh, M. and Hamidi, J. K. (2008): Geotechnical risk assessment based approach for rock TBM selection in difficult ground conditions. Tunnelling and Underground Space Technology, 23, 3, 318-325. doi: 10.1016/j.tust.2007.06.012.

Shang, Y., Xue, J., Wang, S., Yang, Z. and Yang, J. (2004): A case history of tunnel boring machine jamming in an interlayer shear zone at the Yellow river diversion project in China. Engineering Geology, 71, 3-4, 199-211. doi: 10.1016/S0013-7952(03)00134-0.

Shin, H. S., Kwon, Y. C., Jung, Y. S., Bae, G. J. and Kim, Y. G. (2009): Methodology for quantitative hazard assessment for tunnel collapses based on case histories in Korea. International Journal of Rock Mechanics and Mining Sciences, 46, 6, 1072-1087. doi: 10.1016/j.ijrmms.2009.02.009.

Singh, B., Jethwa, J. L., Dube, A. K. and Singh, B. (1992): Correlation between observed support pressure and rock mass quality. Tunnelling and Underground Space Technol- 
ogy incorporating Trenchless, 7, 1, 59-74. doi: 10.1016/ 0886-7798(92)90114-W.

Sousa, R.L. and Einstein, H.H. (2012): Risk analysis during tunnel construction using Bayesian networks: Porto metro case study. Tunnelling and Underground Space Technology, 27, 1, 86-100. https://doi.org/10.1016/j.tust.2011.07.003

Sturk, R., Olsson, L. and Johansson, J. (1996): Risk and decision analysis for large underground projects, as applied to the Stockholm ring road tunnels. Tunnelling and Underground Space Technology, 11, 2, 157-164.

Tzamos, S. and Sofianos, A. I. (2006): Extending the Q system's prediction of support in tunnels employing fuzzy logic and extra parameters. International Journal of Rock Mechanics and Mining Sciences, 43, 6, 938-949.

Yari, M., Bagherpour, R. and Almasi, S.N. (2016): An approach to the evaluation and classification of dimensional stone quarries with an emphasis on safety parameters. Rudarsko-geološko-naftni zbornik (The Mining, Geological and Petroleum Engineering Bulletin), 31, 15-26.

You, K., Park, Y. and Lee, J. S. (2005): Risk analysis for determination of a tunnel support pattern. Tunnelling and Underground Space Technology, 20, 5, 479-486.

Zadeh, L.A. (1965): Fuzzy sets. Information and Control, 8, 3, 338-353.

\section{SAŽETAK}

\section{Modeliranje neizravnom logikom u predviđanju stupnja geotehničkih rizika kod bušenja stijena metodom strojnoga bušenja tunela}

U radu je analiziran stupanj geotehničkoga rizika i iznosa napredovanja kod bušenja tunela u stijenama metodom strojnoga bušenja tunela. Pri tomu je uporabljeno višestupanjsko modeliranje neizravnom logikom. Promatrano je 12 varijabli koje utječu na pojavu geotehničkoga rizika. One su svrstane u 5 skupina obilježenih vrijednostima rizika. Predviđen je model napredovanja bušenjem, na temelju rizika i brzine bušenja. Model je provjeren podatcima iz 58 geoloških zona koje su opažene tijekom bušenja sekcije broj 2 u tunelu Zagros (Iran). Rezultati pokazuju kako je primjena neizravne logike u većini zona dovela do procjene rizika koja je u skladu s terenskim opažanjima. Nadalje, velik iznos koeficijenta determinacije $(0,91)$ između procijenjenoga rizika i prosječnoga stupnja napredovanja u 58 zona potvrdio je primjenjivost modela za predviđanje geotehničkoga rizika. Osim toga, vrijednosti $\mathrm{R}^{2}=0,93$, srednje kvadratne pogrješke o,62 $\mathrm{i}$ varijance 97,51 između izmjerenoga i predviđenoga iznosa napredovanja pokazale su se vrlo uporabljivim za izradbu novoga modela predviđanja stupnja napredovanja.

\section{Ključne riječi:}

geotehnički rizik, bušenje metodom strojnoga bušenja tunela, neizravna logika, tunel Zagros

\section{Authors contribution}

Mohammad Hossein Arbabsiar (Ph.D. candidate) initialized the idea, completed literature review and participated in all work stages, such as data analysis and fieldwork and executed data analysis and tested its accuracy. Mohammad Ali Ebrahimi Farsangi (Associate Professor) and Hamid Mansouri (Associate Professor) managed the whole process and supervised it from the beginning to the end. 